\title{
NETWORKS AND TIES. THE ECONOMICAL POWER HOLDERS OF ALBURNUS MAIOR
}

\begin{abstract}
Alburnus Maior is one of the best-documented and most interesting Roman provincial rural societies. It provided historians with a most complex source: the wax tablets, representing contracts and other juridical documents, hid in a mine gallery when tragedy struck (the Marcomannic attack of $168 \mathrm{AD}$ ) and never recovered by their owners. In the current article, based on micro-historical information offered by these unique sources, we will present an analysis on local society, with a focus on its socio-economical networks, the people which formed them and the ties existing between them.
\end{abstract}

Keywords: wax tablets, contracts, Roman Dacia, Illyrians, ancient mining.
Rada Varga ${ }^{1}$

Babeș-Bolyai University, Cluj-Napoca radavarga@gmail.com

DOI: $10.14795 /$ j.v7i1_SI.500

ISSN 2360 - 266X

ISSN-L 2360 - 266X
$\mathbf{T}$ he settlement of Alburnus Maior (today Roșia Montană, Alba County, Romania) provides one of the most complex economic case studies from the European provinces of the Roman Empire. With a rural status, it was colonized with Illyrian miners ${ }^{2}$ and flourished based on the imperial exploitation of the gold mines from the area. The Illyrian element imprinted on all forms (epigraphic, archaeological) and aspects of life (associative organization, worship, funeral rites), creating a unique environment within Dacia and turning Alburnus into an important historiographical point of interest. The interest was elevated by the discovery of a couple of dozens of wax tablets within the mines, hidden there - and never recovered - in the context of a provincial tragedy, namely the Marcomannic attacks of $168 \mathrm{AD}$. The tablets

\footnotetext{
${ }^{1}$ This work was supported by grants of Ministry of Research and Innovation, CNCS - UEFISCDI, projects number PN-III-P4-IDPCE-2016-0021.

2 HIRT 2019, 5, on the literary and epigraphic sources which validate the Dalmatians' known expertise as miners in the Roman Empire.
} 
are commercial and juridical documents (selling and renting contracts, work contracts, financial institutions founding agreements, official decisions of collegia, etc.), shading light on transactions, prices and most of all economical ties - data that generally elude us for the 'deep' provincial world, especially when dealing with a rural settlement.

Most of the attested inhabitants of Alburnus Maior were not Roman citizens and this hard fact, along with the relative wealth of some peregrines, attracted the historiographical common place of the village life being dominated by non-citizens. While this assumption is partially anchored in reality, using network analyses methods and tools we can see a different facet of the life of Alburnus Maior, with some of the important economic 'gate keepers' attested on the tablets actually being citizens, or having other background than the Illyrian one. The current enterprise will try to establish how wealth and economic power seem to have been distributed among its inhabitants; besides being a relevant case study, the research will also allow us to get a better general overview on economy and society on the northern European limes areas.

\section{THE SETTLEMENT}

Of all the rural communities from Roman Dacia, the only one that is sure to have had peregrine status is Alburnus Maior (Fig. 1). ${ }^{3}$ Most likely, we are dealing with a vicus and its Illyrian inhabitants can be described as an economical diaspora polarized in this area because of the profit coming from mining and mine exploitations. The gold mines were imperial property, administered by a procurator aurarium, whose seat was at Ampelum (modern day Zlatna). ${ }^{4}$ The first procurator is already attested during Trajan's reign and appears to be a person of close confidence for the emperor: Marcus Ulpius Hermias, Augusti libertus. ${ }^{5}$ The pattern of

\footnotetext{
3 For an overview on the subject, see the monographs: DAMIAN 2003; SIMION et alii 2004; DAMIAN 2008; CIONGRADI 2009.

4 PISO 2004.

${ }^{5}$ CIL III 1312
}

having an imperial slave or freedman as procurator will be conserved in time,${ }^{6}$ although not all were procuratores appear to be members of the familia Caesaris. ${ }^{7}$ The exploitations were subsequently sub-contracted to the Illyrians, some of them being real entrepreneurs, overlooking the excavation of entire galleries, others simple miners, contracting work for a given gallery and period of time.

Instituting control over the mineral resources of a newly conquered province was a natural step for the Roman Empire, clear evidence coming from post-conquest northwestern Spain, the short-lived Augustan provincia of Germania, and Britain, where dated ingots and archaeological evidence indicate the commencement or the intensification of metal resource exploitations. ${ }^{8}$

We must be aware from the start of the complexity of this settlement that, in fact, sums up a series of different communities, as well as groups of different ethnicities/ proveniences, legal status and economic situation. The Dalmatians brought to Dacia some of their own forms of organization, such as the kastella. In the Dalmatian world, kastella were rural settlements; at Alburnus they must have been small administrative divisions of the settlement, ${ }^{9}$ more or less comparable to neighborhoods or districts. An inscription dedicated to Diana ${ }^{10}$ mentions kastellum Maniatium, while the well-known dedication for Maelantonius ${ }^{11}$ is set up pro salutae (sic) Maniatium. Although attested in low numbers, the tribe Maniates must have represented one of the significant communities because they are organized administratively and territorially in a kastellum. Kastellum Ansi is one of the best epigraphically represented communities; ${ }^{12}$ Another kastellum, mentioned on epitaphs, is kastellum Starva. ${ }^{13}$ It is attested

\footnotetext{
6 CIL III 1622; CIL III 1088 et alii.

7 CIL III 1311; CIL III 1293 et alii.

8 HIRT 2019, 4.

9 ARDEVAN 2004, 596; PISO 2004, 300; CIONGRADI et alii 2008, 256.

10 BEU-DACHIN 2003, II.

11 AE 1990, 831.

12 AE 1990, 835, 836, 842, 848.

13 AE 2007, 1201; CIONGRADI et alii 2008, Kat. 1.
} 
on only two monuments, both discovered in the necropolis; ${ }^{14}$ although a possible family relationship between the groups of persons is not excluded, it cannot be proven. Another community that might have had a kastellum at Alburnus Maior is that of the Artani. Though not registered explicitly, the hypothesis ${ }^{15}$ that this gens existed in the settlement is connected to the attestation of Dii Artani, a possible tribal divinity. As for the areal/ tribal provenience and appurtenance of other settlers, we have attested Pirustae, original from Dardania (within a vicus Pirustarum), ${ }^{16}$ Baridustae, original from the Bariduum Salonae area (a dedication for the Genio collegi kastelli Baridustarum was conserved), ${ }^{17}$ the Sardiatae (genio collegi Sardiatarum is attested), ${ }^{18}$ etc.

We don't know much on the organization of these communities and the hierarchies existing in the aforementioned administrative unities, but at least one clue is offered by a selling contract, ${ }^{19}$ on which one of the witnesses is Maximus Veneti, princeps. The term is in accordance with Dalmatian realities, as local aristocracy was often denominated in epigraphy as principes of the Delmatae. ${ }^{20}$ It is hard to tell if Maximus had been princeps of a community in Dalmatia and came here with this role (as the community resettled), or if he attained membership of the local elite from Alburnus Maior. ${ }^{21}$ Similar situations in Dacia are encountered and we will mention here only those from Ampelum ${ }^{22}$ and Tihău. ${ }^{23}$ In the case of the inscriptions from Ampelum, the attestation can be interpreted differently and the commemorated character can be

\footnotetext{
14 CIONGRADI et alii 2008, 249.

15 NEMETI 2010, 99-100.

16 CIL III TC 8 = IDR I 9.

17 AE 1944, 24 = IDR III/3, 388.

18 AE 2003, 1487; BEU-DACHIN 2003, I; ARDEVAN/

CRĂCIUN 2003.

19 CIL III TC 6 = IDR I 36.

20 ALFÖLDY 1965, 176-77; WILKES 1969, 287-88; DŽINO 2010,163-64; HIRT 2019, 7.

${ }^{21}$ HIRT 2019, 7.

${ }^{22}$ CIL III 1322 = AE 1968, 443 = IDR III/3, 345.

23 CIL III 838.
}

either a local princeps of the Dalmatians, ${ }^{24}$ or a princeps municipii of the city Splonum, ${ }^{25}$ where he originated from. In the second case the title of princeps is not followed by any relevant detail.

\section{THE PEOPLE}

At this point, we know by name, from epigraphic sources, approximately 190 people form Alburnus Maior. ${ }^{26}$ Of the total number of names, only $61 \%$ come from inscriptions, ${ }^{27}$ the rest being known from the wax tablets. As far as stone inscriptions are concerned, in spite of the recent research and publication of some necropolises and funerary ensembles, ${ }^{28}$ as well as the existence of several funerary epigraphic monuments discovered and published in the past, ${ }^{29} 70 \%$ of the inscriptions from Alburnus Maior are votive. Funerary inscriptions, although not very revealing as a whole because of their low numbers, still offer some interesting data: $66 \%$ of the dead honored with a monument have at least one Italic name (the personal name or the patronymic in the case of peregrine) and $33 \%$ are citizens. This percentage of citizens is observed in both the case of stone monuments and wax tablets. The data suggest a high representativeness of the citizen body at the upper layers of local society and its normal manifestation as a local elite.

Regarding the onomastics, the vast majority of names is Illyrian, but a few remarks are in order. According to $\mathrm{R}$. Katičić, Illyrian onomastics has three main branches: ${ }^{30}$ southern-oriental Dalmatian, central Dalmatian or Dalmatian-Pannonian, and north-Adriatic, from the Liburno-Istrian area. At Alburnus Maior, as I. Piso rightfully observes, ${ }^{31}$ the vast majority of Illyrian names belong to the central onomastic group, thus

\footnotetext{
24 ARDEVAN 1998, 145.

25 LE ROUX 2005, 264.

26 http://romans1by1.com/rpeople/ssearch.

27 PISO 2004; VARGA 2014.

28 SIMION et alii 2004 and DAMIAN 2008.

${ }^{29}$ IDR III/3 and ILD, as compendia where most of the inscriptions can be found.

30 KATIČIĆ 1964, 23.

31 PISO 2004, 290.
} 
indicating the Pannonian-Dalmatine region as preponderant area of provenience for the colonists. As for the structure of the names, we encounter various combinations, which can be typologized according to their 'Latinization' level. ${ }^{32}$ Of course, certain groups must have come into Dacia already partially Romanized, bearing mixed names, ${ }^{33}$ while others probably adopted some Latin onomastic elements only here.

Investors and important businessmen also lived there, to whom the imposing edifices and houses, as the one excavated on the Carpeni hill, belonged. ${ }^{34}$ Epigraphically, they are attested on stone monuments as well as tablets, bearing Latin, Greek and sometimes Illyirian names.

\section{THE WAX TABLETS}

The most representative type of documents from Alburnus Maior are, as already underlined, the wax tablets. They are very important for general Roman mining history, as only one more set of inscriptions concerning this industry exists from the time of the Principate, ${ }^{35}$ namely the ones from Vipasca in Lusitania. The postures in which we find the workers and businessmen of Alburnus in these documents are diverse and stand for the economic complexity of the settlement: they appear as witnesses, ${ }^{36}$ debtors, ${ }^{37}$ buyers, ${ }^{38}$ sellers, ${ }^{39}$ creditors ${ }^{40}$ or guarantors. ${ }^{41}$

The purpose of this study is not detailing upon the content of each wax tablet, as the main actors and their interactions will be lengthily discussed in the social network analyses part, but, nonetheless, a series of particular features

\footnotetext{
32 NEMETI 2015, 133.

33 PÓLAY 1972, 31; MROZEK 1977, 101;

34 BOTA et alii 2003, 433-438.

35 MROZEK 1977, 97.

${ }^{36}$ CIL III TC 1 = IDR I 31; CIL III TC 2 = IDR I 32; CIL

III TC 6 = IDR I 36; CIL III TC 8 = IDR I 39; CIL III TC 10 = IDR I 41.

37 CIL III TC 2 = IDR I 32; CIL III TC 3 = IDR I 33; CIL III TC 5 = IDR I 35.

${ }^{38}$ CIL III TC 6 = IDR I 36; CIL III TC 8 = IDR I 39.

39 CIL III TC 6 = IDR I 36.

40 CIL III TC 13 = IDR I 44.

41 CIL III TC 25 = IDR I 38.
}

stands out and demands special discussions. Thus, we find the collegium of Iovis Cernenus, ${ }^{42}$ where Artemidorus Apolloni and Iulius Iuli are magistri, and Valerius Niconis and Offas Menofili are qaestores. The organization, disbanded through the document, apparently had as its primary purpose offering help for funerals. ${ }^{43}$ The absence of Illyrian names among the heads of the association stands out, although they appear among those of the witnesses (September Platoris, Aelius Plator). Besides the people mentioned above as having some administrative functions in local organizations, at the level of a collegium, or fulfilling the role of princeps, as Maximus Venetis, ${ }^{44}$ we also encounter a certain Massurus Messi, ${ }^{45}$ who is mentioned as decurio. The title is interesting enough, as, if the settlement indeed possessed an ordo decurionum, it is pretty unusual to have a single decurion attested. ${ }^{46}$ No other inscription set up by the members of the order to has ever been discovered, but the peregrine structure of the name makes it impossible for him to have been a decurio in one of the cities of Dacia.

A category of wax tablets worth insisting upon is the one concerned with sales of slaves. In theory, a peregrine could not even appear as witness in a trial concerning mancipatio, ${ }^{47}$ but obviously the provincial realities, as revealed by these legal documents, were different and talk about the flexibility of Roman law and its versatile nature, which made it adaptable to local real-life situations. Thus, through the first contract, ${ }^{48}$ Dasius Verzonis sells a six years old girl to Maximus Batonis. The price of 205 denarii is remarkable; it is a very small sum compared to the general prices paid for slaves in the Empire, ${ }^{49}$ but a realistic

42 CIL III TC 1 = IDR I 31.

43 Similar to the collegium Funeratici Lanuvini, whose Lex colegii is known to us completely (FIRA III 35).

${ }^{44}$ CIL III TC 6 = IDR I 36.

${ }^{45}$ CIL III TC 6 = IDR I 36.

46 PISO 2004, 300.

47 ULPIANUS XX 8.

${ }^{48}$ CIL III TC 6 = IDR I 36.

49 TOMLIN 2003, 48 offers examples for prices of slaves from Italy, Egypt and Londinium where the average sum seems to be around 600 denarii. On the other hand 
mirror of the area's inhabitants' financial possibilities. The small price was also probably due to the young age of the girl that increased the chances of a premature death. Another case $^{50}$ of slave trade is the one where Bellicus Alexandri sells to Dasius Breucus a boy, natio Graeca, whose age is not mentioned but whose price is 600 denarii. The last case ${ }^{51}$ refers to the sale of a woman, natione Creticam - again age is not mentioned - whose price is 420 denarii. The seller and the buyer both have citizen status, the latter being also a miles in legion XIII Gemina. Alexander Antipatri intermediates this transaction, being also a guarantor. As to the few peregrines involved in these transactions it can be noticed that two of them - Dasius Verzonis and Dasius Breucus - have Illyrian names while Maximus Batonis and Bellicus Alexandri have mixed names (the name of Illyrian origin, either the personal one or the patronymic, is followed by a name with Latin origins respectively by a Greek name) and Alexander Antipatri has a full Greek name.

The slave selling contracts bring into focus the financial realities of the place and make us raise the question: what did (relatively) rich mean for Alburnus Maior? Two work contracts provide some data on the local wages. First, Memmius Asclepi, ${ }^{52}$ for a period of 178 days of work in the mines, receives 70 denarii, respectively 0,37 denarii per day (equivalent of 1,5 sesterces). Besides cash, he apparently also received the meals cibarisque. ${ }^{53}$ Aelius Restitutus qui et Senior ${ }^{54}$ receives 105 denarii his employment in the mines. He doesn't seem to receive meals, but an advance of 25 denarii. According to S. Mrozek, a lamb costed 3,6 denarii and a piglet, 5 denarii. ${ }^{55}$ It is difficult to say what these sums really meant at the scale of local economy. For sure, they didn't make the miners 'rich', but the examples he had from Syria and Pamphilia indicate prices between 200-400 denarii.

50 CIL III TC 7 = IDR I 37.

51 CIL III TC 25 = IDR I 38.

52 CIL III TC $10=$ IDR I 41.

53 MROZEK 1977, 103.

54 CIL III TC 11 = IDR I 42.

55 MROZEK 1977, 105. just as certain they were large enough to make the relocation in Dacia and the hard work in itself worthy.

\section{SOCIAL NETWORKS}

The identification of liaisons, groups and networks formed of historical actors has been a constant historiographic preoccupation. Nonetheless, some of the obscured ties can nowadays be revealed in a more ostensible manner by employing technological and sociological tools and methodologies. Social network analysis was developed in the $1960 s^{56}$ and immediately employed in mathematics, anthropology and sociology; it measures structural forms of relations between individuals. ${ }^{57}$ Since their beginnings, SNA became increasingly popular within humanities as well. Initially, SNA studies applied to the ancient world have based their research on archaeological evidence, but literary and epigraphic evidence have been more and more used lately. Expectedly, upperclass groups (from the $5^{\text {th }}$ century Athenian elite to the late Roman aristocracy) and their familial and/or social networks benefit from detailed researches; this tendency is normal, as the informational scarcity which characterizes the provincial low-middle classes can act as a relative drawback. And while classical prosopographic analyses are sometimes impossible or very difficult to render, network analysis gives us the tools to measure the extent of a society's centralization, to identify topographical patterns, and to locate the most central - and yet frequently unstudied figures in its social networks.

For the Greek speaking world, network studies have started to raise the attention of scholars mostly in the last decade, being therefore a relatively young field of research. Of course, as in the case of many new types of researches, the first studies focused on Athens, and on the Mediterranean world. In this area, relevant and comprehensive researches have been carried out by I. Malkin, ${ }^{58}$
56 MILIGRAM 1967.
57 BARABÁSI 2002.
58 MALKIN 2011. 
C. Taylor and K. Vlassopoulos, ${ }^{59}$ but other narrower endeavours have been also achieved. Currently, extensive network studies, based almost exclusively on Egyptian papyri, are being undertaken by the Trismegistos group. ${ }^{60}$ The successful undertaking of these researches supports the need of generating a provincial framework, by applying the concept of 'small-world effect' and by addressing key categories of individuals. Due to the novelty of the approach, network studies have not been integrated on the provincial level of the Roman Empire, and they have not been systematized either. They have rather been used punctually, some examples in this direction being G. Woolf's research on religious phenomena ${ }^{61}$ and G. R. Ruffini's book on Byzantine Oxyrhynchos and Aphrodito. ${ }^{62}$

In the case study we are working on, namely the people attested on the Alburnus Maior wax tablets, SNA was employed in order to highlight the networks and power actors revealed by the sources. Technologically, we used Gephi in order to render the networks. On Fig. 2, each node is a person attested on the wax tablets and the colour stands for juridical status: the peregrines are represented in pink and the citizens in green. The dimension of the nodes in given by the number of connections. Persons attested on the same document are tied by an undirected edge.

The local economic realities as shown by these network models are rather striking. One can easily notice five independent small networks, whose nodes are not connected otherwise (outside the network). Remarkably, one of them is exclusively formed out of peregrines, ${ }^{63}$ and it is exactly the network form which Maximus Veneti, the princeps and Masurus Messi, the decurio, come. The contract in itself deals with the selling of a slave girl, but the presence of these locally high profile men as witnesses might indicate that the seller and buyer are also part of the

\footnotetext{
59 TAYLOR/VLASSOPOULOS 2015.

60 http://www.trismegistos.org/.

61 WOOLF 2016.

62 RUFFINI 2008.

${ }^{63}$ CIL III TC 6 = IDR I 36.
}

settlement's uppers class. This appears to be a more or less closed Illyrian group, definitely situated at the higher layers of Alburnus Maior. Citizens dominate two networks. The first one $^{64}$ involves a legionary soldier, Claudius Iulianus, buying a slave girl in $160 \mathrm{AD}$; it comes as no surprise that most of his witnesses are soldiers or veterans - thus citizens - and only the guarantor is a peregrine. A potentially interesting feature is the activity of the bearers of Greek names in monetary transactions: ${ }^{65}$ in our case, both seller (Claudius Philetus) and guarantor (Alexander Antipatri) have Greek names and other examples can as well be found on different tablets. ${ }^{66}$ The second network also involves the selling of a slave, ${ }^{67}$ in $142 \mathrm{AD}$ this time, and while both seller and buyer are peregrines, the guarantor and most of the witnesses are citizens - one of them, Appius Proclus, being even a veteran of the XIII-th Gemina. Again, the seller has a Greek name. Interesting enough, though separated by almost 20 years, both contracts contain the formula apochatum pro unciis duabus, which actually means that registering the sale and issuing a receipt costed two ounces. ${ }^{68}$ These three networks show us a glimpse into the economy of the local 'elites' (the term is employed with all required reservation), as slaves were for sure luxury products (again, at a local scale). So, these transactions, monetarily important, have as actors Illyrian community leaders and citizens - some of them directly connected and involved in business with the military.

But of course, the truly interesting feature is the central network, formed of more clusters. At this point, we can clearly delimitate, using the centrality degree factor, the main actors, the ones who basically are nodal points of connection between smaller groups, thus uniting them into a large-scale network. In this given network, the number

\footnotetext{
${ }^{64}$ CIL III TC 6 = IDR I 38.

65 MROZEK 1977, 105.

66 Alexander Caricci (CIL III TC 5 = IDR I 35), Iulius Alexander (CIL III TC 3 = IDR I 33), etc.

${ }^{67}$ CIL III TC 7 = IDR I 37.

68 NEMETI 2015, 147.
} 
of involved citizens and peregrines is equal, and so is, on average, their importance, centrality and number of connections. As one can easily notice, the largest node, the man with most connections, is Lucius Vasidius Victor. Nonetheless, his position in this economic web is interesting: though appearing on three documents, ${ }^{69}$ his role is solely as a witness. Nonetheless, he always signs as the first witness and in one instance ${ }^{70}$ his name is in nominative, followed by the mention signavit. ${ }^{71}$ These clues might indicate that, rather than being an economical actor, Vasidius had an official legal capacity, which made him desirable as a witness. The second central character, completely different from Vasidius, is a woman, a peregrine and definitely an economic player, namely Andueia Batonis. She appears on one contract buying half of a house $^{72}$ in vicus Pirustarum, in 159 AD, for 300 denarii, on another ${ }^{73}$ as lending 140 denarii to Iulius Alexander in $162 \mathrm{AD}$, and possibly on a third, ${ }^{74}$ badly deteriorated contract whose nature cannot be determined. As far as the wax tablets reveal, Andueia Batonis is the most active attested entrepreneur we know by name from Alburnus. Unfortunately, we know nothing else about her, family details or adjacent data on her business. On the selling contract, one of the witnesses is Bato Annaei, a character which also appears on another tablet, ${ }^{75}$ unfortunately massively deteriorated. The connection between the two, suggested by onomastics, is appealing, but Bato is a rather common name in the Alburnus Maior community, ${ }^{76}$ so the degree of uncertainty remains rather high in this matter. All in one, it would be more than welcomed if more data on this intriguing female character would show up, but until then, we can only state that she was an active and prosperous local

\footnotetext{
69 CIL III TC 1 = IDR I 31; CIL III TC 5 = IDR I 35; CIL III TC 8 = IDR I 39.

${ }^{70}$ CIL III TC 8 = IDR I 39.

71 MROZEK 1977, 101-102.

72 CIL III TC 8 = IDR I 39.

${ }^{73}$ CIL III TC 3 = IDR I 33.

${ }^{74}$ CIL III TC 2 = IDR I 32.

75 CIL III TC 20 = IDR I 51.

76 PISO 2004, 290.
}

entrepreneur.

These main nodes centralize the network around them and it is safe to assume that (at least most of) the people forming it knew each other and had other direct interactions as well.

\section{FINAL REMARKS}

The wax tablets have the paramount importance of highlighting social and economical aspects of life that no other type of ancient written source reveals. Besides the Illyrian 'colonization' and the groups of colonists which can be delimited due to archaeology and stone epigraphy, they give us the opportunity to see other more of their everyday life and their economic capacity. Even if on a small scale, we can observe, due to them, local entrepreneurs and play doers in all their diversity. As well, they give us the certainty that the 'middle class' of the settlement played an active role and shaped the life and dynamics of the village. To sum up the conclusions, we have a settlement that, while undoubtedly prosperous, is certainly mid-level when it comes to cash inflow. From the social analyses point of view, we see that the Dalmatian 'nobility' operated as a local elite group, dealt among themselves and were attached to their titles. As for how much these titles meant as administrative decision power in Alburnus Maior, the question remains open, but probably they acted at least as intermediates between Roman power and local society. Equally, we underline the high epigraphic presence of citizens - probably higher that the demographic percentage they represented. This detail suggests prosperity and the fact that probably most of the Roman citizens living in Alburnus were local elite or at leas upper mid-layers, economically and socially speaking.

The irony of their initial hiding and modern discovery lies, as in the case of monetary thesauri and other spectacular archaeological discoveries, with the tragedy of their initial hiding, followed by the subsequent tragedy of them never being recovered. Whoever hid them probably didn't live through 
the Marcomannic attack. Nonetheless, these unfortunate circumstances generated one of the most complex sources for understanding the entanglements and interactions (direct or otherwise) of economical actors in Roman rural society and placed Alburnus Maior on the spotlight of provincial socio-economical researches.

\section{REFERENCES}

\section{ALFÖLDY 1965}

Alföldy, G., Bevolkerung und Gesellschaft der römischen Provinz Dalmatien (Budapest: Akadémiai Kiadó).

\section{ARDEVAN 1998}

Ardevan, R., Viața municipală in Dacia romană (Timişoara: Mirton).

ARDEVAN 2004

Ardevan, R., Die Illyrianier von Alburnus Maior. In: H. Heftner, K. Tomaschitz (eds.), Ad fontes! Festschrift für Gerhard Dobesch zum fünfundsechzigsten Geburtstag am 15. September 2004 (Wien), 593-598.

\section{ARDEVAN/CRĂCIUN 2003}

Ardevan, R./Crăciun, C., Le collegium Sardiatarum à Alburnus Maior. In: C. Alonso del Real, P. García Ruiz, Á. Sánchez-Ostiz, J. B. Torres Guerra (eds.), Urbs aeterna. Actas y colaboraciones del coloquio internacional Roma entre la literatura y la historia. Homenaje a la profesora Carmen Castillo (Navarra), 227-240.

BARABÁSI 2002

Barabási, A.-L., Linked: The Science of Networks (Cambridge: Perseus Books Group)

\section{BEU-DACHIN 2003}

Beu-Dachin, E., Două inscripţii votive inedite de la Alburnus Maior, EphNap 13, 187-193.

BOTA et alii 2003

Bota, E./Țentea, O./Voișian, V., Edificiul public din punctual Tomuș (E1). In: Damian, P. (ed.), Alburnus Maior I. (Bucureşti), 433-446.

CIONGRADI 2009

Ciongradi, C., Die römischen Steindenkmäler aus Albvrnvs Maior (Cluj-Napoca: Mega).

CIONGRADI et alii 2008

Ciongradi, C./Timofan, A./Bârcă, V., Eine neue Erwähnung des Kastellum Starva in einer Inschrift aus Alburnus Maior. Studium $\mathrm{zu}$ epigraphisch Bezeugten Kastella und Vici im dakischen Goldbergwerksgebiet, ZPE 165, 249-266.

DAMIAN 2003

Damian, P. (ed.), Alburnus Maior I. (Bucureşti: CIMEC).

\section{DAMIAN 2008}

Damian, P. (ed.), Alburnus Maior III/1. Necropola romană de incineraţie de la Tăul Corna (Cluj-Napoca: Mega).

\section{DŽINO 2010}

Džino, D., Illyricum in Roman Politics 229 $B C-A D 68$ (Cambridge: Cambridge Univ. Press).

HIRT 2019

Hirt, A., Dalmatians and Dacians - forms of belonging and displacement in the Roman Empire, Humanities 8, 1, 1-25. doi:10.3390/ h8010001

\section{KATIČIĆ 1964}

Katičić, R., Namengebung im römischen

Dalmatien, Die Sprache 10, 1, 23-33.

MALKIN 2011

Malkin, I., A Small Greek World. Networks in the Ancient Mediterranean (Oxford: Oxford Univ. Press).

MILIGRAM 1967

Miligram, S., The Small World Problem, Psychology Today 2, 60-67.

\section{MROZEK 1977}

Mrozek, S., Die Goldbergwerke im römischen Dazien, ANRW II.6, 95-109.

\section{NEMETI 2010}

Nemeti, S., Das Kastellum Artum. In R. Marschalko (ed.), Förderung der nachhaltigen Entwicklung im Donauraum durch kulturelle und wissenschaftliche Zusammenarbeit. HumboldtKolleg Cluj-2010 Cluj-Napoca), 98-104.

\section{NEMETI 2015}

Nemeti, I., Esercito e società nella dacia romana. Gli Illiri in ambiente militare, ActaMN 52.I, 131-142.

\section{PISO 2004}

Piso, I., Gli Illiri ad Alburnus Maior. In G. Urso (ed.), Dall'Adriatico al Danubio. L'Illirico nell'età greca e romana (Pisa), 271-307. 


\section{PÓLAY 1972}

Pólay, E., A Dáciai viaszostáblák szerzödései (Budapest: Közgazdasági és Jogi Kiadó).

\section{LE ROUX 2005}

le Roux, P., Peregrini incolae, ZPE 154, 261266.

RUFFINI 2008

Ruffini, G. R., Social networks in Byzantine Egypt (Cambridge: Cambridge Univ. Press).

SIMION et alii 2004

Simion, M./Apostol, V./Vleja, D., Monumentul funerar circular/The circular funeral monument. Alburnus Maior II (Bucureşti:CIMEC).

\section{TAYLOR, VLASSOPOULOS 2015}

Taylor, C./Vlassopoulos, K. (eds.), Communities and Networks in the Ancient World (Oxford: Oxford Univ. Press).

TOMLIN 2003

Tomlin, R. S. O., 'The girl in question': A new text from Roman London, Britannia 34, 41-51.

VARGA 2014

Varga, R., The peregrini of Roman Dacia (ClujNapoca:Mega).

WILKES 1969

Wilkes, J.J., Dalmatia (London: Routledge \& Kegan Paul).

WOOLF 2016

Woolf, G., Only connect? Network analysis and religious change in the Roman world, Helade 2, 2, 43-58.

FIRA

S. Riccobono et alii (eds.), Fontes iuris Romani antejustiniani, Firenze 1940-1943.

ULPIANUS

Domitius Ulpianus, Liber Singularis Regularum (ed. P. Krueger), Berlin, 1987. 


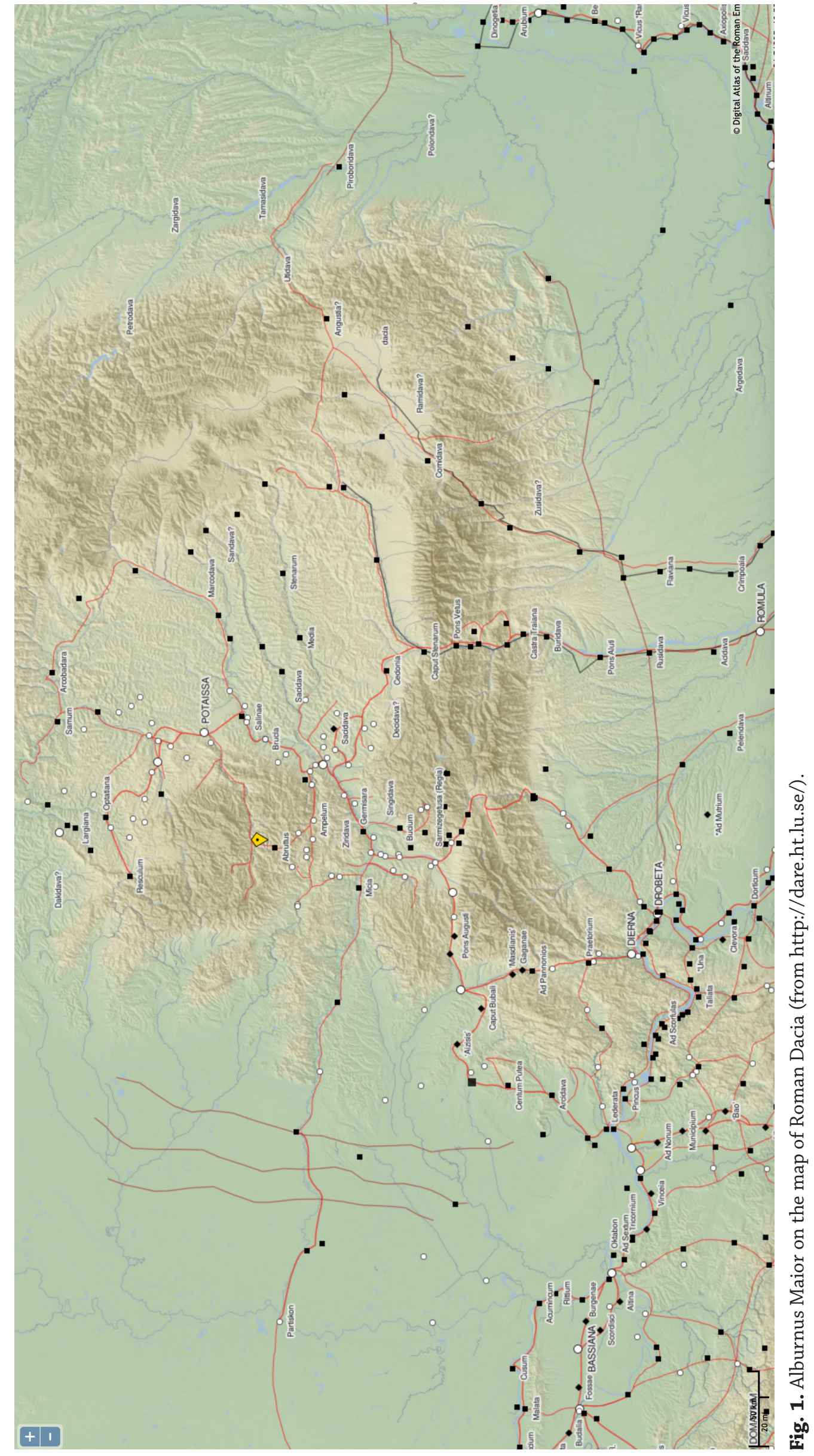




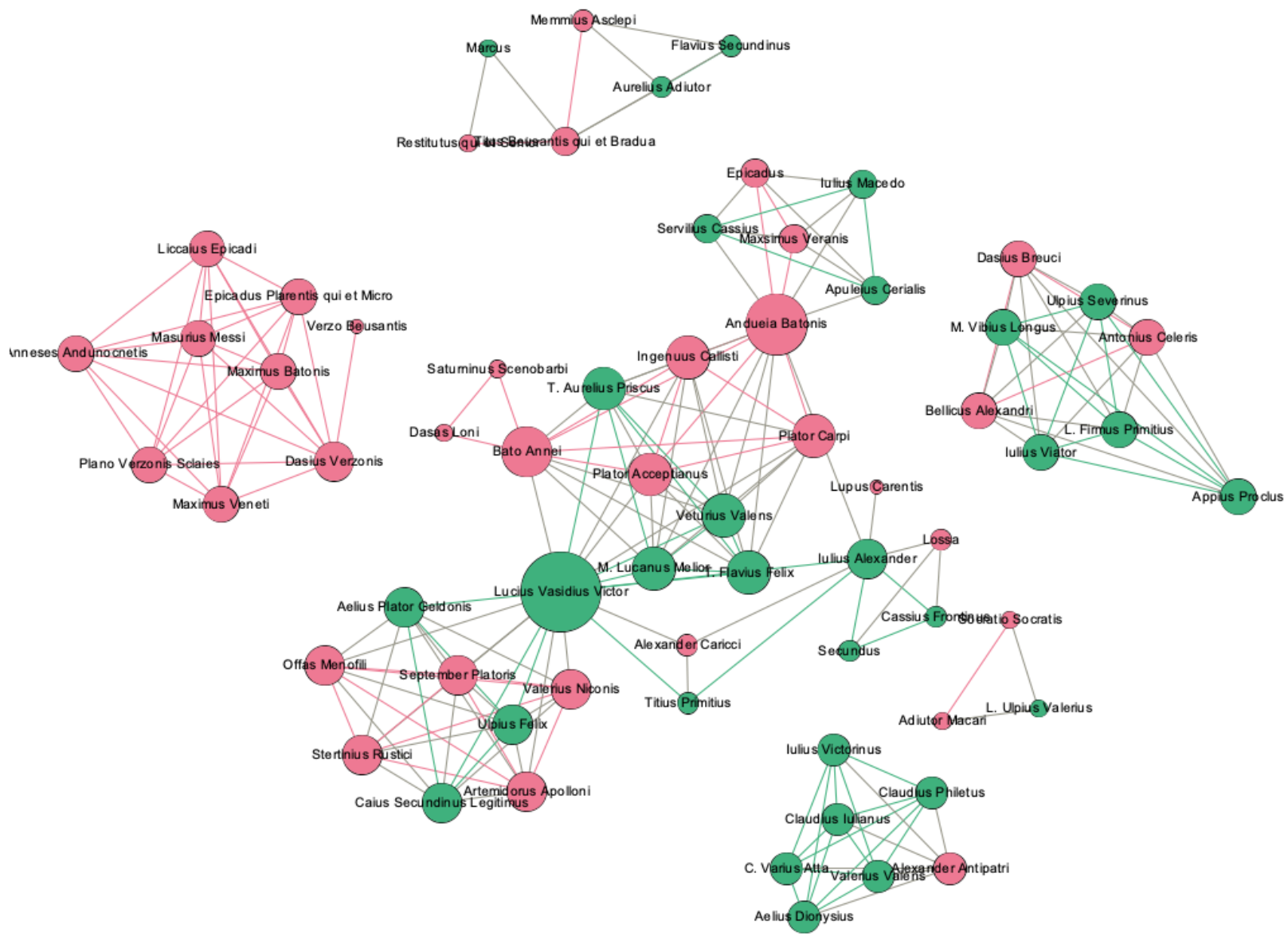

Fig. 2. The network of people attested on the wax tablets generated with Gephi. 
